\title{
Localization of prolactin in chromophobe pituitary adenomas: study of human necropsy material by immunoperoxidase technique
}

\author{
K. KOVACS, B. CORENBLUM, A. M. T. SIREK, G. PENZ, AND C. EZRIN \\ From the Department of Pathology, St. Michael's Hospital and University of Toronto, Toronto, \\ Ontario, Canada
}

SYNOPSIS In order to identify prolactin-producing tumours in human pituitary glands, 45 chromophobe adenomas, obtained from unselected necropsies, have been studied by various staining pro- $Y$ O cedures including the immunoperoxidase technique for the demonstration of prolactin. The presence응 of immunoreactive prolactin was revealed in the cytoplasm of the tumour cells in six cases $(13 \%),-$ indicating that the occurrence of prolactin-producing adenomas is not rare. No correlations were $?$ established between tumours and clinical history. Two adenomas were detected in female and four $\stackrel{0}{3}$ in male patients. The age of the patients at necropsy ranged from 28 to 75 years. Three adenomas were associated with disseminated carcinoma, two with fatal liver disease, and one with diabetes $\varphi$ mellitus, atherosclerosis, and pyelonephritis. Manifest endocrine symptoms were not disclosed, and ${ }^{\circ}$ endocrine investigations, including measurements of blood prolactin levels, were not undertaken. Thus, direct evidence is lacking as to whether or not these tumours were actively secreting prolactin.

In the non-tumorous parts of the anterior lobes the number of prolactin cells was decreased in two cases, suggesting that prolactin released from the adenoma cells suppressed prolactin production in $\frac{\mathrm{D}}{\mathbb{Q}}$ the non-tumorous pituitary. However, the number of prolactin cells of the non-tumorous adenohypophysis seemed to be unchanged in two and increased in another two cases.

The present findings conclusively proved the existence of the prolactin-producing adenomas as a distinct entity. These tumours do not stain with acid or basic dyes, they are PAS or thionin negative, and do not contain immunoreactive growth hormone. Thus, by conventional staining procedures they are indistinguishable from other chromophobe adenoma types. Herlant's erythrosin and? Brookes' carmoisine methods, claimed specifically to stain prolactin cells, failed to provide reliable $\frac{0}{3}$ results, hence their use cannot be recommended in tumour identification. Immunoperoxidase stain- $\delta$ ing of prolactin is the only technique which conclusively reveals the presence of immunoreactive $\frac{3}{3}$ prolactin in the cytoplasm of the tumour cells and permits diagnosis. It is proposed that this tech-o nique be introduced in pituitary morphological studies. Its application may lead to a better under- $>$ standing of problems related to prolactin-producing tumours and their secretory activity.

Although sensitive, specific, and reproducible measurements of pituitary hormones in blood and tissues conclusively proved the existence of a distinct pituitary tumour type, termed prolactin-producing adenoma (Peake et al, 1969; Friesen et al, 1972; Nasr et al, 1972; Guinet et al, 1973; Tolis et al, 1974), the information obtained so far is still too limited regarding incidence, diagnosis, and functional significance of this newly recognized entity. It has recently been shown that a large number of pituitary tumours

Received for publication 11 August 1975 are accompanied by raised blood levels of prolactin $\mathrm{N}^{\circ}$ (Tolis et al, 1974). Hyperprolactinaemia in itself, $\underset{\omega}{N}$ however, does not provide unequivocal evidence as to whether the tumour consists of prolactin cells, since interference with the hypothalamo-adenohypophysial transport of various mediator sub- $\stackrel{-}{+}$ stances might result in enhanced secretion and higher 0 blood concentration of prolactin from the non- $\overline{0}$ tumorous pituitary (Turkington et al, 1971; Tolis $e t \stackrel{\mathbb{\Phi}}{\Phi}$ $a l, 1973$; Boyar et al, 1974). Surgically removed $\frac{\Phi}{\Phi}$ pituitary tumours have recently been investigated by using various histochemical and immunocytological 
techniques as well as by electron microscopy. These studies led to the conclusion that prolactin-producing tumours are not rare (Horvath and Kovacs, 1974; Landolt and Hosbach, 1974; Zimmerman et al, 1974; Kovacs et al, 1975).

Recently, it became evident that various substances could be demonstrated by using immunoperoxidase techniques on formalin-fixed and paraffin-embedded human tissues which had been stored for different lengths of time (Phifer et al, 1970, 1973; Burns et al, 1974). As specific antibodies can be raised against human prolactin (Hwang et al, 1971), we thought it pertinent to apply the immunoperoxidase technique for prolactin localization in human chromophobe adenomas available to us in the form of paraffin blocks from the necropsy material at St. Michael's Hospital. We felt that immunocytological techniques would be helpful in detecting prolactinproducing adenomas, and that they would allow us to assess their incidence, reveal their structural features, and correlate their morphology with the clinical history.

\section{Material and Methods}

Necropsies performed at St. Michael's Hospital over the last 20 years provided the material for our study. The pituitary glands were removed from the sella turcica, cleaned, weighed, fixed in formalin, and embedded in paraffin. They were cut in horizontal planes and stained with haematoxylin-phloxinesaffron. Generally one-half of each gland was embedded and a section or two were made from the block.

In this material 45 pituitary glands were available which contained chromophobe adenomas. The paraffin blocks, stored for various lengths of time (up to 20 years), were recut and the presence of chromophobe adenomas was verified. Sections of 4-6 $\mu$ thickness were then prepared for immunoperoxidase techniques and for various staining procedures.

For immunocytological localization of prolactin and growth hormone the immunoglobulin-enzyme bridge method was used as described by Mason et al (1969) with the following two major modifications: (1) The duration of exposure to the specific antibodies and subsequent reagents was reduced to 10 minutes. (2) Instead of applying horseradish peroxidase and antiperoxidase individually, the horseradish peroxidase-antihorseradish peroxidase complex was used, as proposed by Sternberger et al (1970). In control experiments the specific antibodies were replaced by normal rabbit serum. For comparison, non-tumorous pituitary glands from various necropsy cases (including one pregnant and one lactating woman) were also immunostained for prolactin and for growth hormone.

The actual steps of the technique were as follows: Sections were deparaffinized with toluol, transferred to decreasing concentrations of ethanol, hydrated with phosphate buffered saline (PBS), pH 7.2, for 5 minutes, placed on moist filter paper in a Petri dish, and treated with normal goat serum $(1: 30$ dilution) for 10 minutes in order to block nonspecific background staining. After washing in PBS (4 times, 1 minute each) they were exposed to specific rabbit antiserum (antihuman prolactin, 1:100 dilution; antihuman growth hormone, 1:1000 dilution) for 10 minutes. All antisera were diluted in PBS containing $1 \%$ normal goat serum. After being washed in PBS (4 times, 1 minute each) sections were exposed to goat-antirabbit serum (1:10 dilution) for 10 minutes. After being washed again in PBS (4 times, 1 minute each) they were treated with the horseradish peroxidase-antiperoxidase complex (PAP) (1:15 dilution) for 10 minutes. They were then rewashed in PBS (4 times, 1 minute each) and exposed to DAB solution (3 $\mathrm{mg}$ of 3.3'-diaminobenzidine tetrahydrochloride in $10 \mathrm{ml} 0.05$ tris buffer, $\mathrm{pH} 7 \cdot 6$, to which 3 drops of $3 \%$ hydrogen peroxide were added before use) for 5-10 minutes. After being washed in runnning water for 5 minutes they were treated with $1 \%$ osmium tetroxide for 2 minutes. After being washed in running water for 5 minutes they were dehydrated in increasing concentrations of ethanol, cleared in toluol, and mounted.

The specific antibodies used were antihuman prolactin and antihuman growth hormone. The antihuman prolactin was donated by $\mathrm{Dr} \mathrm{H}$. Friesen (Department of Physiology, University of Manitoba, Winnipeg, Manitoba, Canada). The antihuman growth hormone was obtained from Wellcome Reagents Limited (Beckenham, England). The horseradish peroxidase-antiperoxidase complex was provided by Dr L. A. Sternberger (Basic Sciences Department, Medical Research Laboratories, Edgewood Arsenal, Maryland, USA).

Additional sections were stained with haematoxylin-phloxine-saffron, orange $\mathrm{G}$, Herlant's tetrachrome erythrosin (Herlant, 1960), Brookes' carmoisine (Brookes, 1968), aniline blue, PAS, and aldehyde thionin techniques.

\section{Results}

INCIDENCE

Among 45 chromophobe adenomas six cases (13\%) were found which showed the presence of immunoreactive prolactin in the cytoplasm of the tumour cells by the immunoperoxidase technique. These 
prolactin-containing tumours were regarded as representing prolactin-producing adenomas, ie, adenomas consisting of prolactin cells. Immunoreactive growth hormone was not demonstrated in any of the 45 tumours. The adenoma cells failed to stain with orange $G$, aniline blue, PAS or aldehyde thionin. In non-tumorous pituitary glands melanocorticotroph, gonadotroph, and thyrotroph cells are known to react positively either with PAS or with aldehyde thionin (Ezrin and Murray, 1963).

\section{CLINICAL AND NECROPSY FINDINGS}

The main clinical and necropsy findings are summarized in the table. It can be seen that prolactin cell adenomas were detected in two female and in four male cases. The ages of the patients at necropsy ranged from 28 to 75 years, averaging 57 years. The two female cases belonged to the younger age group while the four male cases were in the older age group. The number of cases is, however, not sufficient for any conclusion to be drawn as regards age differences between women and men. Prolactin cell adenomas were associated with various diseases; three adenomas were disclosed in patients with disseminated carcinoma, two with fatal liver disease and one with diabetes mellitus, atherosclerosis, and pyelonephritis. No correlations were noted between the adenomas and clinical history, main disease, duration of illness, treatment or cause of death. None of the patients had been treated with phenothiazines. In case 2 the necropsy revealed nephrocalcinosis and parathyroid hyperplasia. This patient, however, died of hepatic failure, and her parathyroid function was not investigated. Case 6 had diabetes mellitus for many years and was treated with insulin. In no cases were endocrine examinations undertaken nor were blood prolactin levels measured. Clinical symptoms indicative of enhanced prolactin secretion were not apparent, but it is known that prolactin cell adenomas may be unassociated with manifest endocrine abnormalities (Horvath and Kovacs, 1974; Landolt and Hosbach, 1974; Zimmerman et al, 1974; Kovacs et al, 1975). Thus, in our material, it is possible that prolactin was not only stored but discharged into the circulation as well.

\section{PITUITARY WEIGHT}

Pituitary weights were found to be within normal iู limits in five cases. In the remaining case (case 4) the $\omega$ pituitary was large and friable but it was not weighed.

INTERVAL BETWEEN DEATH AND NECROPSY In the six cases of prolactin cell adenomas necropsy was begun between 2 and 14 hours after death. Immunoreactive prolactin was clearly apparent also in that case (case 4) in which necropsy was started 14 hours after death, indicating that the immunoperoxidase technique for prolactin demonstration can be a valuable approach in necropsy material.

\section{HISTOLOGY OF ADENOMAS}

By using conventional staining procedures the six

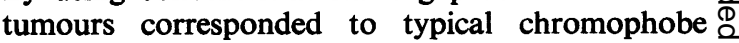
adenomas and failed to exhibit distinctive features $\overrightarrow{\vec{\sigma}}$ permitting their identification as prolactin-produc- 3 ing neoplasms (figs 1 and 2). Although not en-

\begin{tabular}{|c|c|c|c|c|c|c|c|c|}
\hline No. & $\begin{array}{l}\text { Age } \\
\text { (years) }\end{array}$ & $\operatorname{Sex}$ & Main Clinical Findings & $\begin{array}{l}\text { Duration } \\
\text { of Disease }\end{array}$ & Endocrine Changes & $\begin{array}{l}\text { Time } \\
\text { elapsed } \\
\text { between } \\
\text { Death and } \\
\text { Necropsy } \\
\text { (hours) }\end{array}$ & Main Necropsy Findings & $\begin{array}{l}\text { Pituitary } \\
\text { Weight } \\
(g)\end{array}$ \\
\hline
\end{tabular}

\begin{tabular}{|c|c|c|c|c|c|}
\hline 1 & 28 & $\mathbf{F}$ & $\begin{array}{l}\text { Carcinoma sigmoid } \\
\text { colon; widespread } \\
\text { metastases; ascites; } \\
\text { anaemia }\end{array}$ & 2 years & None \\
\hline 2 & 39 & $\mathbf{F}$ & $\begin{array}{l}\text { Jaundice; vomiting, } \\
\text { fever; hepatic coma }\end{array}$ & 1 week & $\begin{array}{l}\text { Parathyroid hyperplasia } \\
\text { (only one gland studied) }\end{array}$ \\
\hline 3 & 64 & $\mathbf{M}$ & $\begin{array}{l}\text { Carcinoma of skin; } \\
\text { widespread carcinomatosis }\end{array}$ & 18 years & None \\
\hline 4 & 65 & $\mathbf{M}$ & $\begin{array}{l}\text { Carcinomatosis; } \\
\text { weakness; ascites }\end{array}$ & 6 months & None \\
\hline 5 & 69 & $\mathbf{M}$ & $\begin{array}{l}\text { Viral hepatitis; loss of } \\
\text { weight; emaciation; } \\
\text { jaundice; haematemesis }\end{array}$ & 3 years & None \\
\hline 6 & 75 & $\mathbf{M}$ & $\begin{array}{l}\text { Diabetes mellitus; fever; } \\
\text { azotaemia; cardiac } \\
\text { failure }\end{array}$ & Many years & Diabetes mellitus \\
\hline
\end{tabular}

Adenocarcinoma sigmoid 0.6 colon with metastases; bronchopneumonia

Massive hepatic necrosis; 0.5 nephrocalcinosis

Squamous carcinoma 0.5 skin with metastases; bronchopneumonia

Adenocarcinoma stomach with metastases pulmonary embolism Postnecrotic liver cirrhosis; gastrointestinal haemorrhage; bronchopneumonia

Diabetes mellitus; atherosclerosis; acute and chronic pyelonephritis, bronchopneumonia 
capsulated, they were usually sharply demarcated from the surrounding non-tumorous pituitary. Their size varied from case to case. In five cases the tumours were small and replaced only less than a quarter of the adenohypophysis, whereas in one case (case 4) the tumour was large and occupied more than half of the anterior lobe. The adenomas were fairly cellular and richly vascularized. In some areas the tumour cells were arranged in cords and occasionally formed acinus-like patterns. The connective tissue stroma was inconspicuous in all but one case (case 6) in which the presence of hyalinous connective tissue among the tumour cell cords was prominent. Mitotic figures were infrequent and no pleomorphism was observed. The nuclei of the tumour cells were well developed, usually round, rather poor in chromatin, and possessed prominent nucleoli. The cytoplasm was scanty and failed to stain with the conventional acid or basic dyes, PAS technique or thionin. Secretory granules were not apparent. Immunoperoxidase technique, using antihuman growth hormone for growth hormone localization, yielded negative results. In three cases, by using Herlant's tetrachrome technique, a few erythrosinophil secretory granules were detected in the cytoplasm of some tumour cells, which in two cases also stained with Brookes' carmoisine. In three cases staining was achieved neither with Herlant's erythrosin nor with Brookes' carmoisine techniques.

The distinguishing feature of the six adenomas was the presence of immunoreactive prolactin in the cytoplasm of the tumour cells (figs 3, 4, and 5).
Brown deposits were seen in the cytoplasm, usually arranged in streaks, frequently adjacent to the nucleus or to the plasma membranes, possibly in or around the rough-surfaced endoplasmic reticulum membranes and/or the Golgi sacculi. As no definite secretory granules were identified, the question of whether or not they reacted positively cannot be answered with certainty. In general, the intensity of staining was uneven and varied somewhat not only from case to case but also from cell to cell. In some cells the positivity was strong and brown deposits almost completely filled the cytoplasm.

\section{HISTOLOGY OF NON-TUMOROUS PITUITARY}

The non-tumorous parts of the anterior lobes in the six cases of prolactin cell adenomas were compared with the tumour free areas of those 39 pituitary glands which, by histology, showed the presence of chromophobe adenoma but failed to exhibit a positive immunoperoxidase reaction for prolactin. By using various staining procedures, including the immunoperoxidase technique for growth hormone demonstration, no differences were found between the two groups.

Immunostaining for prolactin, however, revealed considerable differences in the non-tumorous parts of the anterior lobes among the six cases of prolactin cell adenomas. In two cases in the tumour free areas the number of prolactin cells was strikingly reduced, and only very few or no prolactin cells were identified (fig 6). In two other cases the number of prolactin cells was comparable to that seen in the control glands. In the remaining two cases, however,

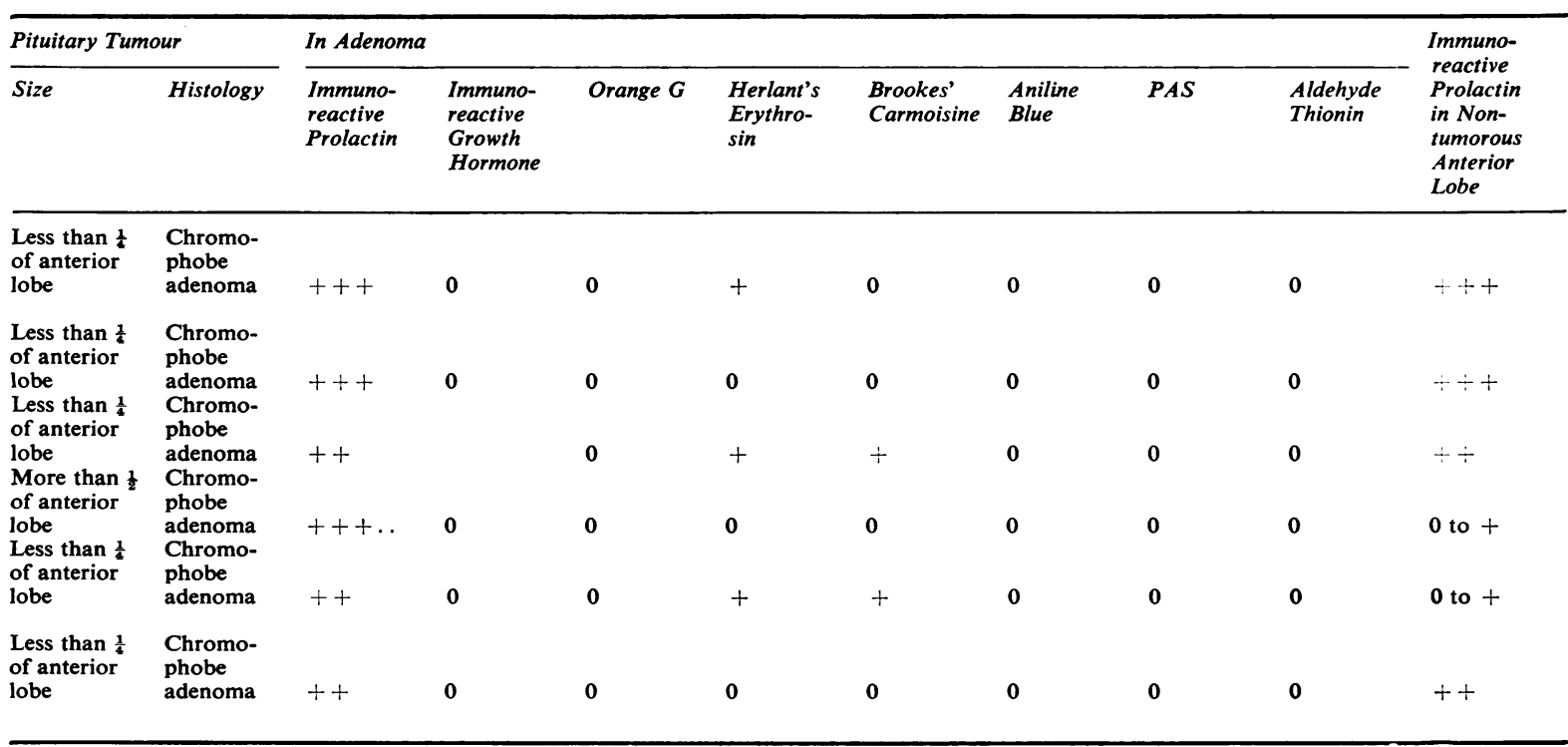




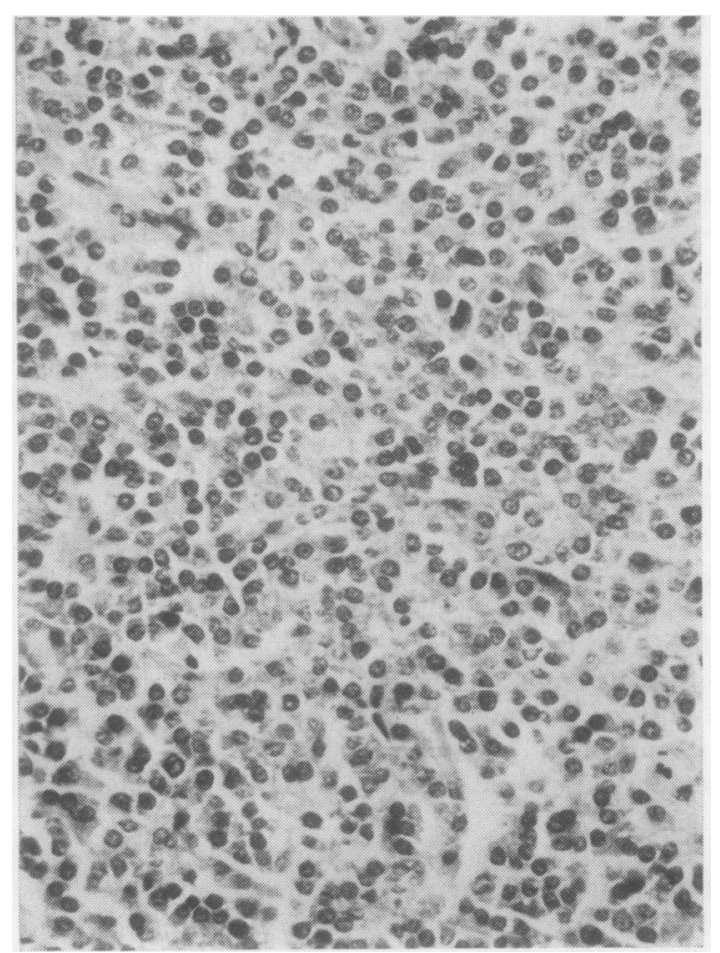

Fig 1 Case 4. Histological appearance of the tumour is consistent with the diagnosis of chromophobe adenoma (haematoxylin-phloxine-saffron $\times$ approx 250).

many prolactin cells were apparent (fig 7). They were scattered at random throughout the entire anterior lobes, in some areas arranged in nests or cords. Occasionally small nodules consisting of prolactin cells were formed.

\section{Discussion}

Previous studies using various immunocytological methods revealed the presence of immunoreactive prolactin in animal and human pituitary glands as well as in some pituitary adenomas (Pasteels et al, 1972; Moriarty, 1973; Ueda et al, 1973; El Etreby and Günzel, 1974; Merchant, 1974; Zimmerman et al, 1974; Kovacs et al, 1975). Our present work is, however, the first to demonstrate immunoreactive prolactin by the immunoperoxidase technique in pituitary chromophobe adenomas obtained from unselected human necropsies. The fact that these human pituitary glands, having been fixed in formalin some hours after death and then stored in the form of paraffin blocks for various lengths of time, are suitable for immunocytological prolactin localization, provides a unique opportunity to investigate problems related to the secretion of this adenohypophysial hormone.

Although numerous efforts have recently been made to assess the incidence of prolactin secreting adenomas (Tolis et al, 1974; Zimmerman et al, 1974; Kovacs et al, 1975), the question how frequently these tumours occur has not been conclusively established so far. The syndrome of enlarged sella turcica, amenorrhoea, and galactorrhoea is indicative of this tumour type (Herlant et al, 1965; Lamotte et al, 1966; Linquette et al, 1967, 1972; Tolis et al, 1974). Some prolactin-producing tumours are, however, unassociated with manifest symptomatology (Horvath and Kovacs, 1974; Zimmerman et al, 1974; Landolt and Hosbach, 1974; Kovacs et $a l, 1975)$. Hyperprolactinaemia in itself cannot be regarded as an unequivocal evidence of prolactin secretion by the tumour because increased blood prolactin levels may also occur in cases of non-

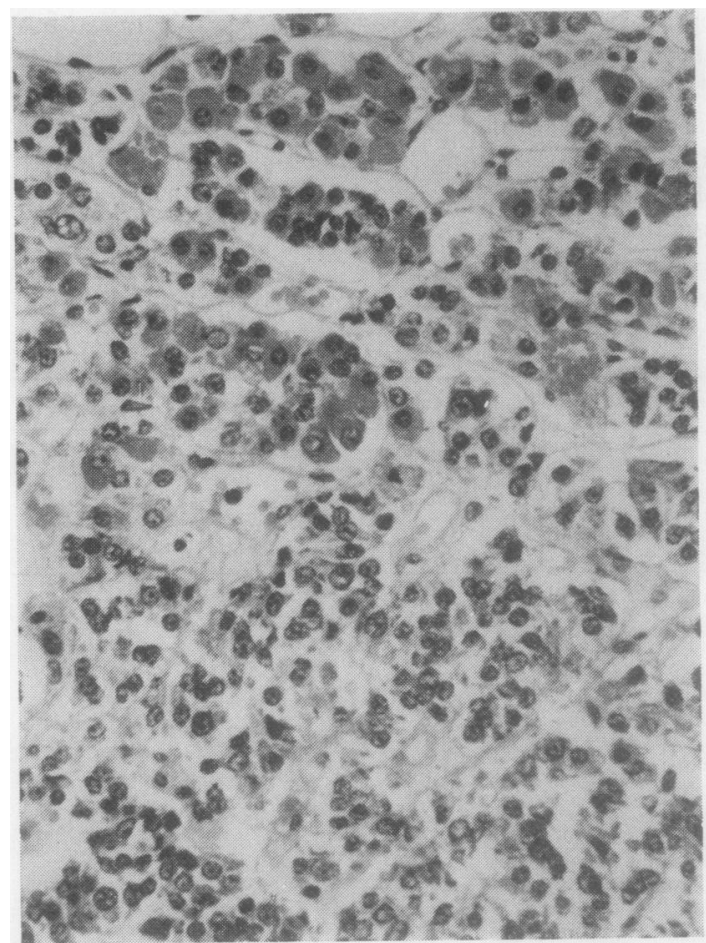

Fig 2 Case 2. Although not encapsulated, the adenoma is easily distinguishable from the non-tumorous adenohypophysis. The adenoma cells cannot be identified as prolactin cells by using conventional staining procedures (haematoxylin-phloxine-saffron $\times$ approx 250). 


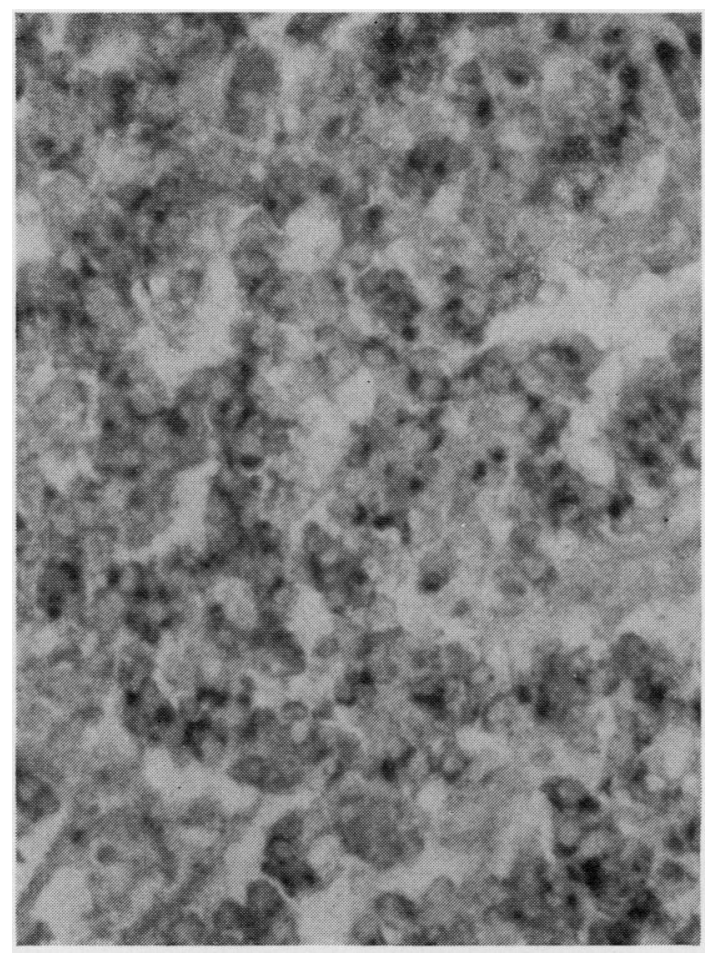

Fig 3 Case 1. Immunoreactive prolactin is evident in the cytoplasm of adenoma cells (immunoperoxidase staining for prolactin $\times$ approx 100).

prolactin-producing tumours or in non-neoplastic conditions (Turkington et al, 1971; Tolis et al, 1973; Boyar et al, 1974). Prolactin-producing chromophobe adenomas cannot be recognized conclusively by conventional light microscopy and cannot be distinguished from other pituitary tumour types. Electron microscopy, which is a very valuable tool (Mirouze et al, 1969; Racadot et al, 1971; Guinet et al, 1973; Horvath and Kovacs, 1974; Lewis and van Noorden, 1974; Landolt and Hosbach, 1974; Kovacs et al, 1975) in detecting these tumours, cannot be applied on necropsy material because of autolysis. The immunoperoxidase technique is the only method at present which permits identification of these tumours.

Among 45 chromophobe adenomas, six cases $(13 \%)$ were found to contain immunoreactive prolactin in the cytoplasm of the tumour cells, indicating that the occurrence of this adenoma type is not rare. The question how closely these figures represent the real incidence cannot be answered with certainty at present. Serial sections were not cut from the pituitary glands, and it is possible that some cases

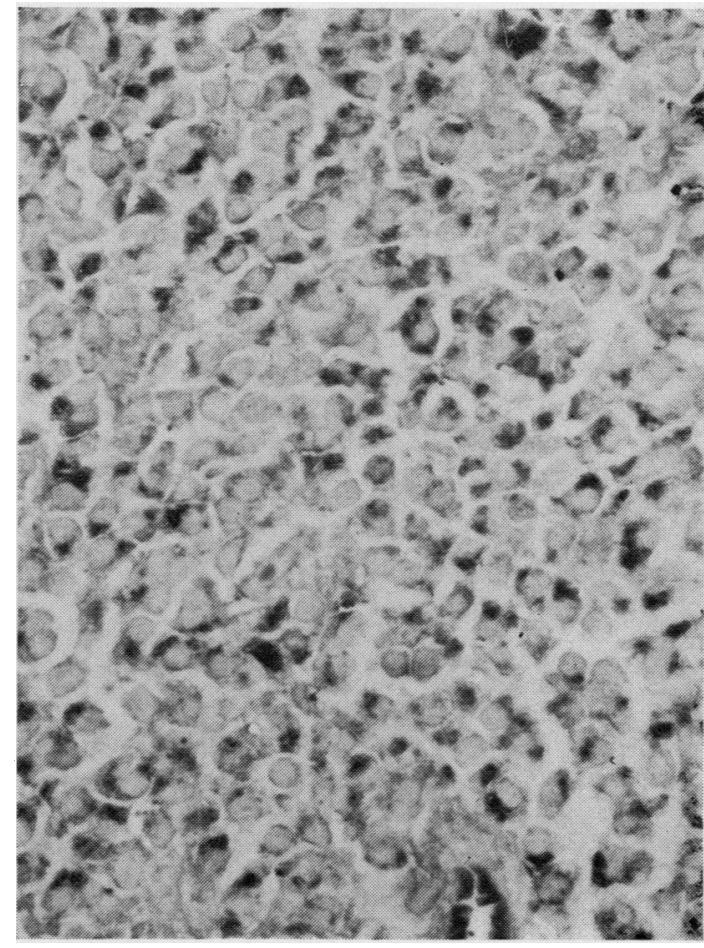

Fig 4 Case 4. Distribution of immunoreactive prolactin is uneven in the adenoma cells (immunoperoxidase staining for prolactin $\times$ approx 400 ).

might have been overlooked. Some tumours may have been missed because of improper fixation or embedding or because the antigenic determinants in the tumour tissue were altered or bound. One may also suppose that some prolactin-secreting adenomas release all the hormones they produce, and if they are not capable of storing prolactin they will not stain with the immunoperoxidase technique and will be considered as representing other tumour types.

Immunoreactive prolactin was demonstrated in streaks in the cytoplasm of the tumour cells, suggesting that the specific antibody used in the present work recognized immunoreactive prolactin in or around the rough-surfaced endoplasmic reticulum membranes and/or Golgi complexes. Correlative light and electron microscopic investigations of surgically removed pituitary tumours showed that some chromophobe adenomas corresponded to sparsely granulated prolactin cell adenomas (Horvath and Kovacs, 1974; Kovacs et al, 1975). These tumours contained only few and small secretory granules, which could be disclosed by electron microscopy but only inconclusively by light 


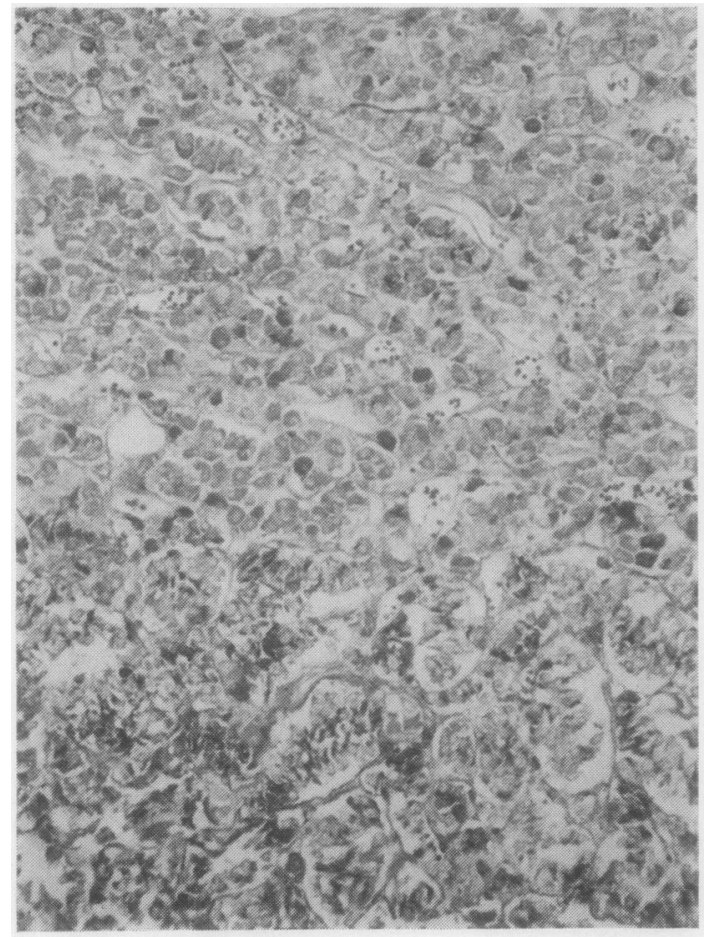

Fig 5 Case 2. The adenoma consists of prolactin cells. Numerous prolactin cells are also apparent in the non-tumorous adenohypophysis (immunoperoxidase staining for prolactin $\times$ approx 100$)$.

microscopy. The six adenomas investigated in the course of the present study obviously belong to this entity. Thus, it is not surprising that no definite views could be expressed as to whether or not secretory granules reacted positively with the immunoperoxidase technique at the light microscopic level. Ultrastructural cytochemistry is needed to elucidate the exact sites where prolactin is localized. Nakane (1971), studying pituitaries by electron nicroscopy, noted that immunoreactive prolactin might be present not only in the secretory granules but also in the rough-surfaced endoplasmic reticulum membranes and Golgi complex. Parsons and Erlandsen (1974), however, using the ultrastructural immunoperoxidase technique, localized prolactin exclusively to the secretory granules in nontumorous rat pituitaries.

It was noteworthy that we failed to obtain satisfactory results by using Herlant's erythrosin (1960) and Brookes' carmoisine (1968) techniques, which are claimed specifically to stain secretory granules of prolactin cells (Herlant and Pasteels, 1967;

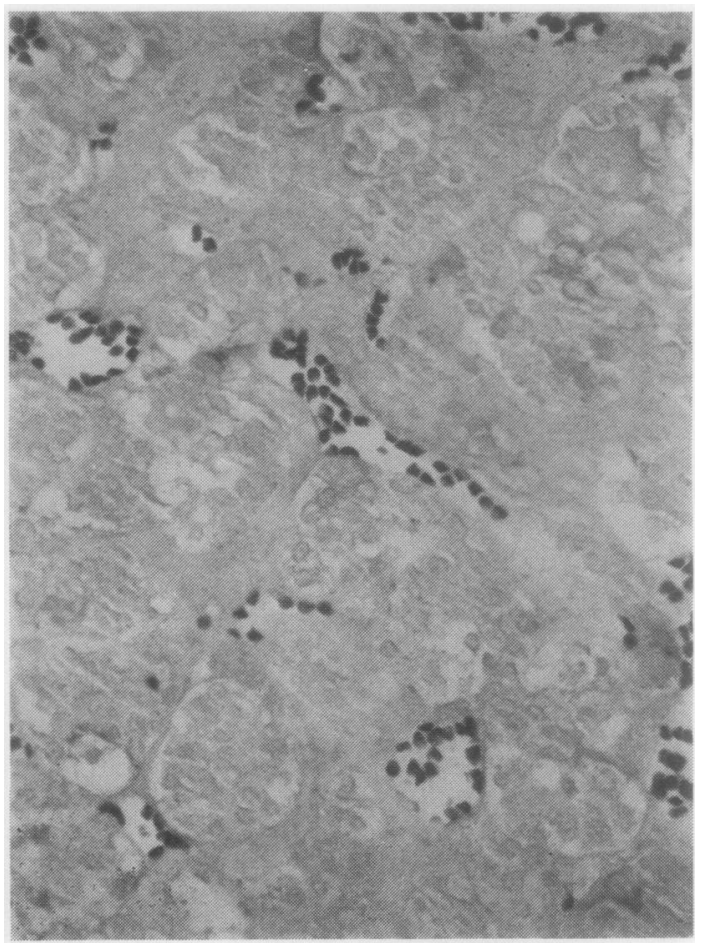

Fig 6 Case 5. No prolactin cells are seen in the non-tumorous adenohypophysis (immunoperoxidase staining for prolactin $\times$ approx 250 ).

Peake et al, 1969; Pasteels et al, 1972; El Etreby and Günzel, 1974). Among the six cases in which immunoreactive prolactin was detected, only three cases stained with Herlant's erythrosin, two of which also stained with Brookes' carmoisine technique. Hence, our findings seem to indicate that these two staining procedures cannot be reliably applied in identification of prolactin secreting tumours. Similar views have also been expressed by other authors. Pakurar et al (1975) observed that in organ cultures of the rat pituitary more cells stained with the immuno- $N$ peroxidase technique used for prolactin detection $\mathrm{C}_{\mathrm{C}}$ than with Herlant's method. Zimmerman et al (1974) noted indefinite and inconstant results with Brookes' carmoisine staining technique on surgically removed human prolactin-producing adenomas.

In the present work not only the adenomas but also the non-tumorous parts of the pituitary glands were investigated for cytological details and for the presence of immunoreactive prolactin. The fact that in two cases the number of prolactin cells in the nontumorous part of the adenohypophysis was de- 


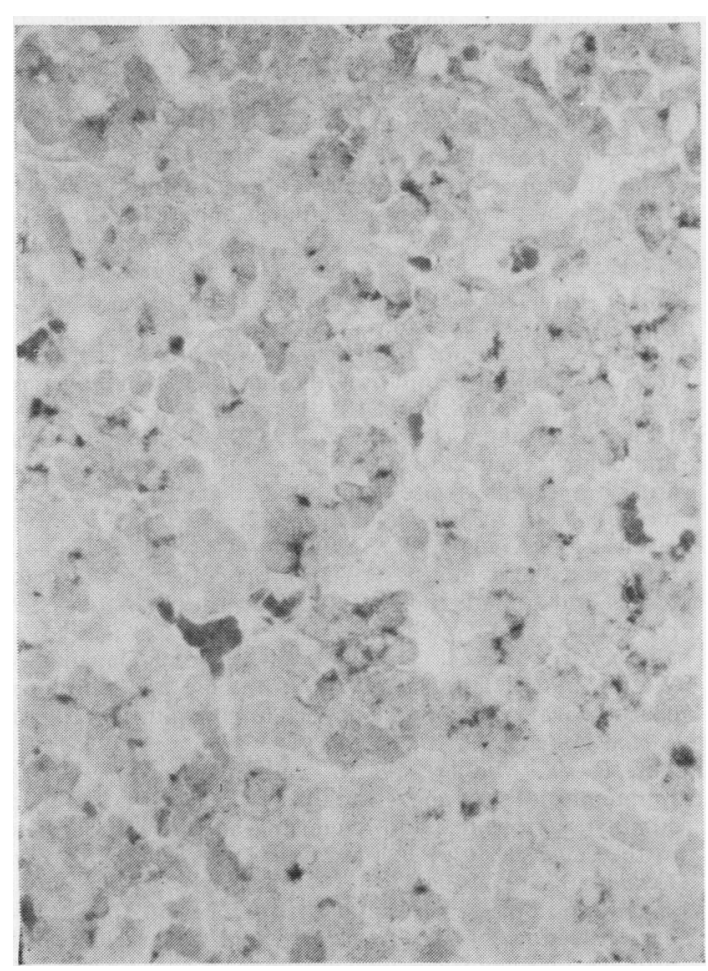

Fig 7 Case 1. Numerous prolactin cells are evident in the non-tumorous adenohypophysis (immunoperoxidase staining for prolactin $\times$ approx 250$)$.

creased or almost completely absent compared with the appropriate control material seems to suggest that prolactin released from the adenoma can exert a negative feedback effect on non-tumorous prolactin cells. This view is consistent with the findings of other investigators (MacLeod et al, 1966; Chen et al, 1967; Nakayama and Nickerson, 1973; MacLeod and Lehmeyer, 1974) who disclosed involution of prolactin cells, reduced RNA content as well as decreased prolactin synthesis and release in the pituitaries of rats bearing implanted prolactin secreting hypophysial neoplasms.

The regulatory mechanisms affecting prolactin secretion seem, however, to be much more complicated. Since in two cases no decrease of non-tumorous prolactin cells occurred, one has to presume that either prolactin was not released by these two tumours in sufficient amount, or, due to some interfering factor, it was not capable of blocking its own production in the non-tumorous parts of the pituitary. It is still more difficult to explain the remaining two cases, in which the number of prolactin cells was increased in the non-tumorous adenohypophysial tissue. Great caution is needed when one attempts to interpret these morphological findings in terms of secretory activity. The number of prolactin cells is known to vary considerably depending upon sex, age, hormonal status, etc, even in normal subjects (Herlant and Pasteels, 1967; Pasteels et al 1972; El Etreby and Günzel, 1974). Because of marked individual differences it is not justified to draw definite conclusions based on such a small number of heterogeneous cases. There are other factors which complicate the evaluation of the results. Serial sections were not cut, nor was the number of prolactin cells quantitatively assessed in the non-tumorous adenohypophyses, nor were prolactin levels measured in blood and pituitaries. Despite all these reservations our findings seem to suggest that the non-tumorous adenohypophyses are not affected uniformly by the presence of prolactinproducing adenoma.

We wish to thank Dr H. Friesen, Department of Physiology, University of Manitoba, Winnipeg, Manitoba, Canada for providing the antihuman prolactin and Dr L. A. Sternberger, Basic Sciences Department, Medical Research Laboratories, Edgewood Arsenal, Maryland, USA for the peroxidase-antiperoxidase complex. The excellent technical assistance of Miss Nancy MacPhail and the valuable secretarial help of Mrs Maureen Rowling are appreciated. The work was supported in part by MA-552 grant of the Medical Research Council of Canada and by the St. Michael's Hospital Research Society.

\section{References}

Boyar, R. M., Kapen, S., Finkelstein, J. W., Perlow, M., Sassin, J. F., Fukushima, D. K., Weitzman, E. D., and Hellman, L. (1974). Hypothalamic-pituitary function in diverse hyperprolactinemic states. J. clin. Invest., 53, 15881598.

Brookes, L. D. (1968). A stain for differentiating two types of acidophil cells in the rat pituitary. Stain Technol., 43, 41-42.

Burns, J., Hambridge, M., and Taylor, C. R. (1974). Intracellular immunoglobulins: a comparative study on three standard tissue processing methods using horseradish peroxidase and fluorochrome conjugates. J. clin. Path., 27, 548-557.

Chen, C. L., Minaguchi, H., and Meites, J. (1967). Effects of transplanted pituitary tumors on host pituitary prolactin secretion. Proc. Soc. Exp. Biol. (N. Y.), 126, 317-320.

El Etreby, M. F. and Günzel, P. (1974). Sex hormoneseffects on prolactin cells in the rat, dog, monkey and man: histomorphological and immunocytochemical studies. Acta endocr. (Kbh.), 76, Suppl. 189, 1-15.

Ezrin, C. and Murray, S. (1963). The cells of the human adenohypophysis in pregnancy, thyroid disease and adrenal cortical disorders. In Cytologie de l'Adenohypophyse, edited by J. Benoit and C. Da Lage, pp. 183-199. Centre National de la Recherche Scientifique, Paris.

Friesen, H., Webster, B. R., Hwang, P., Guyda, H., Munro, R. E., and Read, L. (1972). Prolactin synthesis and secretion in a patient with the Forbes Albright syndrome. $J$. clin. Endocr., 34, 192-199. 
Guinet, P., Girod, C., Pousset, G., Trouillas, J., and L'Hermite, M. (1973). Un cas d'adénome à cellules à prolactine: dosage de prolactine, étude au microscope électronique, résultats post-opératoires. Ann. Endocr. (Paris), 34, 407-417.

Herlant, M. (1960). Ètude critique de deux techniques nouvelles destinées à mettre en évidence les différentes catégories cellulaires présentés dans la glande pituitaire. Bull. Micr. appl., 10, 37-44.

Herlant, M., Laine, E., Fossati, P., and Linquette, M. (1965). Syndrome aménorrhée-galactorrhée par adénome hypophysaire à cellules à prolactine. Ann. Endocr. (Paris), 26, 65-71.

Herlant, M. and Pasteels, J. L. (1967). Histophysiology of human anterior pituitary. Meth. Achiev. exp. Path., 3, 250305.

Horvath, E. and Kovacs, K. (1974). Misplaced exocytosis: distinct ultra-structural feature in some pituitary adenomas. Arch. Path., 97, 221-224.

Hwang, P., Guyda, H., and Friesen, H. (1971). A radioimmunoassay for human prolactin. Proc. Nat. Acad. Sci., (Wash.), 68, 1902-1906.

Kovacs, K., Horvath, E., Corenblum, B., Sirek, A. M. T., Penz, G., and Ezrin, C. (1975). Pituitary chromophobe adenomas consisting of prolactin cells: a histologic, immunocytological and electron microscopic study. Virchows Arch. path. Anat., 366, 113-123.

Lamotte, M., Houdart, R., Pasteels, J., Perrault, M. A., Cauche, R., and Segrestaa, J. M. (1966). Adénome hypophysaire prolactinique. Presse méd., 74, 1025-1030.

Landolt, A. M. and Hosbach, H. U. (1974). Biological aspects of pituitary tumors as revealed by electron microscopy. Pathologica, 66, 413-436.

Lewis, P. D. and van Noorden, S. (1974). "Nonfunctioning" pituitary tumors: a light and electron microscopical study. Arch. Path., 97, 178-182.

Linquette, M., Fossati, P., Lefebvre, J., Derrien, G., Buvat' J., and Laine, E. (1972). Adénomes hypophysaires à cellules lactotropes et adénomes avec galactorrhée. Rev. franc. Endocr. clin., 13, 11-29.

Linquette, M., Herlant, M., Laine, E. Fossati, P., and Dupont-Lecompte, J. (1967). Adénome à prolactine chez une jeune fille dont la mère était porteuse d'un adénome hypophysaire avec aménorrhée-galactorrhée. Ann. Endocr. (Paris), 28, 773-780.

MacLeod, R. M. and Lehmeyer, J. E. (1974). Influence of hormone-secreting pituitary tumors on RNA biosynthesis in rat anterior pituitary. $J$. nat. Cancer Inst., 52, 823-828.

MacLeod, R. M., Smith, M. C., and DeWitt, G. W. (1966). Hormonal properties of transplanted pituitary tumors and their relation to the pituitary gland. Endocrinology, 79, 1149-1156.

Mason, T. E., Phifer, R. F., Spicer, S. S., Swallow, R. A., and Dreskin, R. B. (1969). An immunoglobulin-enzyme bridge method for localizing tissue antigens. J. Histochem. Cytochem., 17, 563-569.

Merchant, F. W. (1974). Prolactin and luteinizing hormone cells of pregnant and lactating rats as studied by immunohistochemistry and radioimmunoassay. Amer. J. Anat., 139, 245-268.

Mirouze, J., Jaffiol, C., Mary, P., Baldet, P., and Monnier, L. (1969). Deux syndromes originaux "AménorrhéeGalactorrhée" par tumeur hypophysaire. Discussion anatomo-clinique. Ètude ultrastructurale de l'un eux. Ann. Endocr. (Paris), 30, 810-821.

Moriarty, G. C. (1973). Adenohypophysis: ultrastructural cytochemistry. A review. J. Histochem. Cvtochem., 21 , 855-894.

Nakane, P. K. (1971). Application of peroxidase-labelled antibodies to the intracellular localization of hormones Acta endocr. (Kbh.), 67, Suppl. 153, pp. 190-204.

Nakayama, I. and Nickerson, P. A. (1973). Suppression of anterior pituitary in rats bearing a transplantable growth hormone and prolactin-secreting tumor (Mt T-W10). Endocrinology, 92, 516-524.

Nasr, H., Mozaffarian, G., Pensky, J., and Pearson, O. H (1972). Prolactin-secreting pituitary tumors in women. $J$ clin. Endocr., 35, 505-512.

Pakurar, A. S., Kahn, R. H., and Conklin, J. L. (1975) Immunochemical staining of the rat adenohypophysis in organ culture. Anat. Rec., 181, 131-148.

Parsons, J. A. and Erlandsen, S. L. (1974). Ultrastructura immunocytochemical localization of prolactin in rat anterior pituitary by use of the unlabelled antibody enzyme method. J. Histochem. Cytochem., 22, 340-351.

Pasteels, J. L., Gausset, P., Danguy, A., Ectors, F., Nicoll, C. S., and Varavudhi, P. (1972). Morphology of the lactotropes and somatotropes of man and rhesus monkeys. $J$ clin. Endocr., 34, 959-967.

Peake, G. T., McKeel, D. W., Jarett, L., and Daughaday, W. H. (1969). Ultrastructural, histologic and hormona characterization of a prolactin-rich human pituitary tumor J. clin. Endocr., 29, 1383-1393.

Phifer, R. F., Midgley, A. R., and Spicer, S. S. (1973). Immunohistologic and histologic evidence that folliclestimulating hormone and luteinizing hormone are presen in the same cell type in the human pars distalis. $J$. clin Endocr., 36, 125-141.

Phifer, R. F., Spicer, S. S., and Orth, D. N. (1970). Specific demonstration of the human hypophyseal cells which produce adrenocorticotropic hormone. J. clin. Endocr., 31, 347-361.

Racadot, J., Vila-Porcile, E., Peillon, F., and Olivier, L. (1971). Adénomes hypophysaires à cellules à prolactine étude structurale et ultra-structurale corrélations anatomocliniques. Ann. Endocr. (Paris), 32, 298-305.

Sternberger, L. A., Hardy, P. H., Jr., Cuculis, J. J., and Meyer, H. G. (1970). The unlabelled antibody enzyme method of immunohistochemistry: preparation and properties of soluble antigen-antibody complex (horse radish peroxidase-antihorseradish peroxidase) and its use in identification of spirochetes. J. Histochem. Cytochem. 18, 315-333.

Tolis, G., Goldstein, M., and Friesen, H. G. (1973) Functional evaluation of prolactin secretion in patients with hypothalamic-pituitary disorders. J. clin. Invest., 52 , 783-788.

Tolis, G., Somma, M., van Campenhout, J., and Friesen, H. (1974). Prolactin secretion in sixty-five patients with galactorrhea. Amer. J. Obstet. Gynec., 118, 91-101.

Turkington, R. W., Underwood, L. E., and van Wyk, J. J. (1971). Elevated serum prolactin levels after pituitary-stalk section in man. New Engl. J. Med., 285, 707-710.

Ueda, G., Moy, P., and Furth, J. (1973). Multihormonal activities of normal and neoplastic pituitary cells as indicated by immunohistochemical staining. Int. J. Cancer, 12 , 100-114.

Zimmerman, E. A., Defendini, R., and Frantz, A. G. (1974) Prolactin and growth hormone in patients with pituitary adenomas: a correlative study of hormone in tumor and plasma by immunoperoxidase technique and radioimmunoassay. $J$ clin. Endocr., 38, 577-585. 